\title{
MS-13: The Making of America's Most Notorious Gang. By Steven Dudley. Toronto, Canada: Hanover Square Press, 2020.
}

Pamela Ruiz, Ph.D. Independent Consultant

Follow this and additional works at: https://digitalcommons.usf.edu/jss pp. 165-167

\section{Recommended Citation}

Ruiz,, Pamela Ph.D.. "MS-13: The Making of America's Most Notorious Gang. By Steven Dudley. Toronto, Canada: Hanover Square Press, 2020.." Journal of Strategic Security 14, no. 3 (2021) : 165-167.

DOI: https://doi.org/10.5038/1944-0472.14.3.1978

Available at: https://digitalcommons.usf.edu/jss/vol14/iss3/9

This Book Review is brought to you for free and open access by the Open Access Journals at Digital Commons @ University of South Florida. It has been accepted for inclusion in Journal of Strategic Security by an authorized editor of Digital Commons @ University of South Florida. For more information, please contact digitalcommons@usf.edu. 
MS-13: The Making of America's Most Notorious Gang. By Steven Dudley. Toronto, Canada: Hanover Square Press, 2020. 


\section{MS-13: The Making of America's Most Notorious Gang. By Steven Dudley. Toronto, Canada: Hanover Square Press, 2020 . ISBN-13: 9781335005540. Hardcover. 352 Pages. \$18.26.}

Reviewed by Pamela Ruiz

In MS-13 The Making of America's Most Notorious Gang, Dudley counters the common misperceptions regarding MS-13 and argues the gang is a "social and criminal community" that has been birthed from policies implemented by the United States and El Salvador. Dudley's intimate description of Norman, Cristian, Alex, and Alma's personal histories and gang involvement narrates the duality of gang membership a perspective that neither romanticizes nor criminalizes youth involvement with gangs. In sum, Dudley has written the book I have always wanted to read about MS-13: a humanistic perspective of gang members' duality and larger macro forces that contribute to gang membership.

Dudley describes gang members as "victims and victimizers" and denotes the "gang's central paradox: the MS- 13 is a surrogate family and vicious criminal organization" (p. 17). Through the personal histories of Norman and Alma, Dudley provides vivid examples of how these youth are victims at a young age and when involved with the gang become victimizers. Throughout the book Dudley provides historical components of Norman's life, as a victim: A child who witnessed rebels execute a soldier, experienced his father abandon his mother who then fell into depression, his siblings fleeing to the United States, and finding a surrogate family in the gang; and as a victimizer: once a gang member, Norman, "robbed, extorted, and murdered," and when incarcerated was beaten and fought in bloody riots (p. 21-22).

Dudley's incorporation of Alma's personal history reflects how women's victimization can lead to gang membership. As a victim Alma, was beaten by her father and berated by her mother after she had been raped by her step grandfather (p. 164), and the gang became a "reprieve from her own abuse, an escape hatch, and alternate community," (p. 165), and became involved in drug use to forget her rape. As a victimizer, Alma: extorted her godmother, pretended to be kidnapped with her girlfriend and when her 
father cut off their relationship, she burned his car (p. 276). Dudley does leave academics wishing he'd pull from the vast literature of "victimoffender overlap" regarding gang members to further support what he's labeled "victim and victimizers." Nonetheless, Dudley achieves a higher purpose in writing these stories - he brings a humanistic perspective to MS-13 gang members that are too often exclusively portrayed as vicious killers.

Lastly, Dudley provides the story of Cristian who imminently highlights the ineffectiveness of gang databases and racial biases. Cristian had been granted relief from deportation after entering the U.S. as a minor (p. 251). When attending Huntington high school, a School Resources Officer accused him of being a gang member for "associating" with MS-13 gang members (p. 267-269) - a clear victim of racial profiling. Cristian was deported because he was no longer a minor. Cristian's story leaves the reader wondering how often this injustice has occurred.

Dudley details the unintended and counterproductive consequences of interknitting gang injunctions with immigration/deportation policies. He provides the historical context of Community Resources Against Street Hoodlums (CRASH) units created to counter violence by "finding and incarcerating suspected gang members" (p. 74). By mid 1980, the Immigration and Naturalization Service began to work with CRASH units to "deport suspected gang members" (p. 125). He also provides the example of the 1988 Operation Hammer where dozens were arrested, none were charged, and where the city of Los Angeles ended up paying \$4 million in damages (p. 104-105). By 2000, CRASH units were disbanded due to "fabricating evidence and testimonies, filing fake police reports, and evidence theft;" moreover, "racial profiling, widespread abuse and harassment, and CRASH's regular use of excessive force" also led to a $\$ 100$ million lawsuit against the police (p. 146-147). Dudley draws parallels of counterproductive practices exported to El Salvador which replicated patterns of excessive use of force, arresting "suspected" gang members, and contributing to cycles of violence.

Dudley highlights the "deeply flawed" gang databases due to the lack of "consensus on what constitutes a gang member" allowing officers discretion and adding individuals on an "ad hoc" basis (p. 135). These inaccurate databases are then used by authorities for deportation 
proceedings (p. 135). He details the use of "Alice in Wonderland statute," the Racketeer Influenced and Corruption Organizations (RICO) Act to prosecute leaders who are distant from an organization's daily activities (p. 149). Pointing out that while RICO was successful against the Mexican Mafia and an $18^{\text {th }}$ Street gang case, it was questionable whether it should be applied to MS-13 since the gang lacked hierarchy, organization, and financial solvency (p. 149). Moreover, Dudley also points out the flaws of MS-13 being categorized as a transnational criminal organization by the U.S. Treasury Department, detailing an interview with a federal agent who laughed at the classification and described this as a "pissing match" over US government resources where "the gangs had thousands not millions of dollars" (p. 237).

Dudley's understanding of the gang's complexity is clear in how he interlaces personal stories and their relationship with policies; however, at times the multiple stories, countries, and time periods can cause confusion. Dudley does leave the reader yearning for an explanation of how violence becomes a cohesive factor for a gang that is known for its violence, though he admits this could be a book of its own. Even with these minor imperfections, Dudley's book provides lessons learned regarding counterproductive policies for policymakers to hold present when developing policies, reminds academics to keep present the victimization of gang members when conducting research, and teaches journalists to critically think when reporting on transborder issues. 